\title{
The interpretation of Shi-mo-he-yan-lun (釈摩訶衍論) of Saisen (済暹) seen mainly with Ben-ken-mitsu-ni-kyo- ron-ken-kyo-sho (辨顕密二教論懸鏡抄)
}

\section{ToYoshima Yūgo}

\section{Introduction}

Shi-mo-he-yan-lun is one of the annotated books of Da-cheng-qi-xin-lun (大乗起信論), and describes the work of Nāgārjuna. It is a forgery, and thought to be approved by China or the Silla Kingdom in the first half of the eighth century. Da-cheng-qi-xin-lun-yi-ji (大 乗起信論義記) written by Fa-chang (643-712, 法蔵) and Da-cheng-qi-xin-lun-yi-shu (大乗 起信論義疏) written by Yuan-shao (617-686, 元暁) are famous as the annotated books of Da-cheng-qi-xin-lun. Shi-mo-he-yan-lun is also seen as an influence on Da-cheng-qi-xinlun-yi-ji and is considered to be an annotated book of the Kegon study. However, Shi-mohe-yan-lun sets up a new structure of 33 types of dharma and gates (fa-men, 法門) and the bu-er-mo-hen-yan (the absolute teaching of buddha, 不二摩訶衍), for example. These are the original interpretations not seen in Da-cheng-qi-xin-lun. In Japan, Kukai (774-835, 空海) valued this work and it came to occupy an important position in the Shingon study.

Saisen (済暹, 1025-1115, who was the monk of Ninna-ji (仁和寺) temple at the end of the Heian era) also treated Shi-mo-he-yan-lun as an authentic work written by Nāgārjuna. He wrote the annotated books on the Shaku-ma-ka-en-ron-ketsu-gi-ha-nan-e-shaku-sho (䐆摩訶衍 論決疑破難会釈抄) and Shaku-ron-ryu-gi-bun-shaku (釈論立義分釈). I wrote the thesis concerning Shaku-ron-ryu-gi-bun-shaku in $2005^{1)}$. However, there is a lot of other Saisen's writing. The whole image of the interpretation of Saisen's Shi-mo-he-yan-lun is not clear.

Moreover, at the end of the Heian era, the systematization of the Tendai study had been almost completed by Annen (841-?, 安然); however, the systematization was late in the Shingon study. And the system of the Shingon study was attempted while receiving Annen's influence. Saisen was the pioneer and the trial and error process is witnessed in his interpretation. In this thesis, I verify Ben-ken-mitsu-ni-kyo-ron-ken-kyo-sho, and the contradictions between this and other writings is clarified. This comparison will clarify his pioneer's 
The interpretation of Shi-mo-he-yan-lun (勫摩訶衍論) of Saisen (済暹)

seen mainly with Ben-ken-mitsu-ni-kyo-ron-ken-kyo-sho (辨顕密二教論懸鏡抄)（Y. ToYosHIMA）

character.

\section{The quotation of Shi-mo-he-yan-lun in Ben-ken-mitsu-ni-kyo-ron:}

In Ben-ken-mitsu-ni-kyo-ron, Kukai tried to clarify that the difference between esoteric Buddhism (密教) and other forms of Buddhisms (顥教) are remarkable, but esoteric Buddhism is supreme. For confirmation, he discusses many esoteric Buddhism sutras, among other things. Shi-mo-he-yan-lun is one of the evidences. The quotation part of Shi-mo-heyan-lun divides into two sections. This section consisting of five types of words (五種言語), two types of names (二種名字), and ten states of minds (十種心量) is taken up in the latter half. I would like to witness the interpretation of the all-one mind (多一心) and the oneone mind ( - -心) in ten states of minds. The ten states of minds given by Shi-mo-he-yanlun involve the five sensory organs (eye, ear, nose, tongue, body) and five minds (consideration, manas, ālaya-vijnāna, the all-one mind, the one-one mind). Since the eight states of minds are the same as the eight recognition theories among these, the details are omitted. However, the ninth mind and the tenth mind include the original theory of Shi-mo-he-yan-lun, as the following explains.

The all-one mind is called yi-qie-ji-yi yi-xin (the one mind has the feature that all minds are one mind, 一切即一一心) and the one-one mind is called yi-ji-yi yi-xin (the one mind has the feature that an individual mind is one mind, 一即一一心). These explanations are raised in the interpretation section of the second volume for the analysis of the two types of dharma. These are the san-zi-Mahāyāna (Mahāyāna that divides into three parts, 三自摩訶衔) and the yi-ti-Mahāyāna (Mahāyāna that was integrated into one, 一体摩訶衍). In Shi-mo-he-yan-lun, the one mind is divided into two stages and, in addition, it divides from the viewpoint of the change gate (生滅門) and the truth gate (真如門) into two. These two Mahāyāna correspond to the change gate and the truth gate of the second stage. Therefore, the alias of the san-zi-Mahāyāna corresponding to the change gate is the all-one mind, and the alias of the yi-ti-Mahāyāna corresponding to the truth gate is the one-one mind.

Though the truth is assumed to be verbalized and not to be perceivable in Buddhism originally, it is assumed that it is expressed and perceivable in Shi-mo-he-yan-lun. The five types of words, two types of names, and ten states of minds explain this. In this interpretation the one-one mind expresses the truth, whereas the all-one mind cannot.

Conversely, Shi-mo-he-yan-lun explains the bu-er-mo-hen-yan is the absolute buddha's 
teaching which is irrelevant to indrya (機根). It is a concern whether the truth is the same as the bu-er-mo-hen-yan. This problem cannot be answered clearly from the text, and the interpretation is also a point of contention between researchers. In the structure of the 33 types of dharma, these become the mind of the second stage. From the opinion of whether this relates to the truth, these two minds might relate to the bu-er-mo-hen-yan, if it is thought that the bu-er-mo-hen-yan is the same as the truth. In short, these two minds divide into the two types of classifications; the type seen from the truth and the type seen from the structure of 33 types of dharma.

Kukai thought the bu-er-mo-hen-yan to be related to the truth and interpreted esoteric Buddhism as the bu-er-mo-hen-yan. He thought that it was interpreted to correspond to the absolute bu-er-mo-hen-yan, esoteric Buddhism, and related the one-one mind to this. $\mathrm{Ku}-$ kai considered that there is a gate to the absolute bu-er-mo-hen-yan and that the gate is the one-one mind. This interpretation was disregarded in the structure of 33 types of dharma, and it influenced the following Shingon study. Naturally, Saisen also has succeeded Kukai's interpretation. However, it comes to face the interpretation of the mind of the second stage that Kukai disregarded when Saisen annotates Shi-mo-he-yan-lun. Both of these two interpretations are used when his understanding of Shi-mo-he-yan-lun is observed, and a contradiction is created. I would like to clarify this point.

\section{The Interpretation of the all-one mind and the one-one mind in Ben-ken- mitsu-ni-kyo-ron-ken-kyo-sho:}

In Ben-ken-mitsu-ni-kyo-ron-ken-kyo-sho there is one sentence, “多一識心者是三自一 心本法也 此即心生滅門之所依與行與相如來藏是也”2) The all-one mind is described here as the san-zi-yi-in Mahāyāna (Mahāyāna that divides into three parts on one mind, 三自一心 摩訶衍). The san-zi-yi-in Mahāyāna is located in the mind of the first stage. Therefore, it is understood that it is sincerely located in the highest rank, and the interpretation is different from Shi-mo- he-yan-lun.

Saisen describes the one-one mind, “一一識心者是即示不二性德海法也” ${ }^{3)}$. The oneone mind is related to the the bu-er-mo-hen-yan. This interpretation is the same as Kukai's.

Saisen located the all-one mind to the san-zi-yi-in Mahāyāna and the one-one mind to the bu-er-mo-hen-yan. The interpretation of Kukai's Ben-ken-mitsu-ni-kyo-ron is thought to be a reason. In Ben-ken-mitsu-ni-kyo-ron, Kukai located the Kegon study below esoteric 
Buddhism, and considered the Kegon study to be the san-zi-yi-in Mahāyāna. Therefore, the all-one mind corresponds to the san-zi-yi-in Mahāyāna because the one-one mind corresponds to the bu-er-mo-hen-yan. Next, I will explain the interpretation of these two states of minds of Ryu-gi-bun-shaku (the writing of Saisen), and to compare their different points.

\section{The Interpretation of the all-one mind and the one-one mind in Ryu-gi-bun-shaku:}

It is explained “但第二重能所四法 以此二門爲所依一心法 謂多一心一一心是也”,4) and “第二重所依多一心一一心之二法” "5) by Ryu-gi-bun-shaku. It is understood that the all-one mind and the one-one mind are located in the second stage of the one mind. Therefore, it can be said that Saisen's interpretation in Ryu-gi-bun-shaku is the same as Shi-mohe-yan-lun.

We observe the relation to ju-ju-shin (the minds classified into ten stages, 十住心) continuously described in Ben-ken-mitsu-ni-kyo-ron. Here, the point to interpret the all-one mind as ichi-do-mu-i-shin (一道無為心) is given attention. Saisen interprets ichi-do-mu-i-shin as the second stage because 'kai-san-xian-yi' (開三顕一) is explained in Fa-hua-jing (法華経) and there is no content of san-da (三大) in the first stage. ${ }^{6)}$ It is understood that the relation between tri-yāna and eka-yāna is made repeatedly in the relation between all and one in the mind. When you see the explanation concerning the five questions and answers (五重 問答) and 16 dharma described hereto, the one-one mind is allocated in the third question and answer as well as the all-one mind. ${ }^{7)}$ These two minds are the gates to the san-zi-yi-in Mahāyāna because the gate of the first stage is corresponding to the dharma of the second stage. The interpretation of Saisen's duplicity is the second stage.

To summarize, the influences of the five questions and answers are received, and the allone mind and the one-one mind are one set located below the san-zi-yi-in Mahāyāna.

\section{Conclusion}

The all-one mind and the one-one mind explained by Shi-mo-he-yan-lun are located in the second stage, when observed from the structure of 33 types of dharma. Each mind deals with the change gate and the truth gate. Kukai thought the truth to be the bu-er-mo-henyan. For the one-one mind he made it correspond to the bu-er-mo-hen-yan. Conversely, he made the san-zi-yi-in Mahāyāna correspond to the Kegon study. Kukai's interpretation deviates from the understanding of Shi-mo-he-yan-lun. This interpretation doesn't become 
(156) The interpretation of Shi-mo-he-yan-lun (䣋摩訶衍論) of Saisen (済暹)

seen mainly with Ben-ken-mitsu-ni-kyo-ron-ken-kyo-sho (辨顕密二教論奬鏡抄) (Y. ToYosHIMA)

a problem alone, however contradiction is created when correspondence is requested between Shi-mo-he-yan-lun and his interpretation. Saisen was exactly confronted with this problem. Saisen wrote Ryu-gi-bun-shaku as an annotated book on Shi-mo-he-yan-lun. In this book, he interpreted the all-one mind and the one-one mind as the second stage. This relates to Kukai's interpretation of the five questions and answers and was cincided with the understanding of Shi-mo-he-yan-lun. Saisen wrote the annotated book on Kukai's Benken-mitsu-ni-kyo-ron. In this book, he interprets the all-one mind as the san-zi-yi-in Mahāyāna and the one-one mind as the the bu-er-mo-hen-yan. This interpretation corresponds to the interpretation of Kukai. However, it is different from the interpretation of Shi-mohe-yan-lun. In conclusion, he cannot solve this problem as long as the two books are compared. This frankly shows that Saisen is a pioneer. However, it is necessary to think about other writings for Saisen to be able to finally solve this problem. I propose to address this in future tasks.

1) Toyoshima, Y. [2005], Saisen's Interpretation of the Shi moheyan lun: Focusing on the interpretation of funi-mon, journal of Indian and Buddhist Studies 108 (54-2)

2) Ben-ken-mitsu-ni-kyo-ron-ken-kyo-sho, T77, p.456, c21-22

3) Ben-ken-mitsu-ni-kyo-ron-ken-kyo-sho, T77, p.457, a3-4

4) Ryu-gi-bun-shaku, T69, p.577, b11-13

5) Ryu-gi-bun-shaku, T69, p.577, b14-15

6) Ryu-gi-bun-shaku, T69, p.579, c10-13

7) Ryu-gi-bun-shaku, T69, p.580, b8-10

〈Key Word〉済暹, 釈摩訶衍論, 䀣鏡抄, 多一心, 一一心

(Graduate student, University of Tokyo) 